\title{
Hiland Hall's "Report on Incendiary Publications": A Forgotten Nineteenth Century Defense of the Constitutional Guarantee of the Freedom of the Press
}

\author{
Edited with an Introduction by RICHARD R. JOHN*
}

On 25 March 1836, Vermont Congressman Hiland Hall presented to Congress a remarkable report. Hall was troubled by a number of bills that had come before the House Committee on the Post Office and Post Roads to restrict the transmission of abolitionist publications in the mail, and as a member of this committee felt it incumbent to make his objections known. Hall's report detailed his reservations to the proposed bills and closed with a ringing defense of the constitutional guarantee of a free press.

Hall hoped his report would widen the terms of debate. Prior to March 25, no prominent public figure had openly questioned the authority of Congress to pass some kind of restrictive legislation. Hall's report challenged the constitutionality of any limitation on the freedom of the press, rebutting, point by point, the various rationales for these restrictions that had been advanced by President Andrew Jackson, Postmaster General Amos Kendall, and South Carolina Senator John C. Calhoun.

Hall failed to achieve his goal. No sooner had he tricd to present his report than he was ruled out-of-order. Hall may have hoped to widen the terms of debate, yet his congressional colleagues had other ideas.' As a consequence, Hall never had the chance to read his report aloud nor even to enter it into the official record. It was published neither in the official compendia of congressional documents that have come to be known as the so-called serial set, nor in either the Congressional Globe or the Register of Debates, the semiofficial transcripts of congressional proceedings.

Hall refused to be deterred by these rebuffs and on April 9 published his report in the National Intelligencer, a Washington newspaper known for its extensive coverage of national affairs. 2 It was signed by Hall and

*Richard R. John is an associate professor of history at the University of Illinois at Chicago. He would like to thank Michael Kent Curtis, Robert P. Forbes, Tyler Resch, Diane Simon, David Waidstreicher, and William M. Wiecek for their help in preparing this piece. He would aiso like to thank the Park-McCullough Housc, North Bennington, Vemont, for permission to reprint Hall's corrected version of his report on the abolitionist mails.

1. Register of Defenst, 24th Cong., 1st sess., 25 March 1836, 2944-2946.

2. Hiland Hall, Proposed Report . . On Incendiary Publications, Washington National INTELL.IGENCER, 9 April 1836. 
George N. Briggs, a Massachusetts Congressman and fellow member of the post office committee. Hall readily conceded that, notwithstanding the endorsement of two Congressmen, his report had no standing as a public document. On the contrary, it was merely an "individual argument, divested of all official character." To underscore his point, Hall titled the report "proposed." Hall recognized that his decision to seek publication in this non-official forum would strike some as irregular, but he refused to be deterred. "Several members of the House," Hall explained, in justification of his decision, had urged him in writing to publish his report, and neither he nor Briggs felt at liberty to decline their request. After all, Hall reasoned, "no argument denying the power of Congress over the subject has hitherto been given to the public."3

Hall's failure to get a hearing within Congress sparked a considerable amount of speculation among contemporaries sympathetic to his ideas. According to his Hall's son, his father's report had been rejected because the majority of the post office committee declined to make a report of its own, making a minority report unnecessary. 4 Others charged that it had been deliberately suppressed. The House committee failed to act, insinuated one New York editor, because it was "ashamed, apparently openly, to recommend" the "suppression" of the abolitionist publications that President Jackson had advocated, but lacked the "manliness and true patriotism" to challenge the president directly. 5 Later commentators were even more forthright, and blamed the majority's decision on the determination of a malignant "slave power" to stifle public discussion of the abolitionists' cause. 6

The controversy over the abolitionist mails has long been familiar to historians of the period. Hall's report, however, is not. Notwithstanding the considerable historical literature on this controversy and the even more extensive body of writing on the freedom of the press, it remains unknown even to specialists in the history of constitutional law. 7 This

3. Hiland Hall to Gales and Seaton, 6 April 1836, in WaShINGTON NaTIONAL INTELLIGENCER, 9 April 1836. In a joumal cntry that Hals datcd 25 March 1836, but which he almost certainly wrote long after the fact, Hall declared that he had "prepared and published" a "minority report on incendiary publications." In this entry, Hall presumably contlated the initial presentation of his report before Congress with its eventual publication, since there is no record of its publication prior to 9 April. Hiland Hall Journal, Hiland Hall Papers, ParkMcCullough House, North Bennington, Vermont.

4. Henry D. Hali, Memoir of Hon. Hiland, LL. D., New-England Historical and Geneological Register 41 (1887): 12 For a more cxtended discussion of Hall's public career, see Tyler Resch, The Meticulous Advocate: Hiland Hall of Vermont-A Biography (unpublished manuscript in author's possession).

5. The Liberty of the Press, New-York American, country edition, 29 April 1836.

6. Jacob Ul.lery, Comp., Men of Vermont: An Illustrated Biographical. History of Vermonters and Sons of Vermont (Brattleboro: Transcript Publishing Company, 1894), 94.

7. One index of the scholarly neglect of Hall's report is its absence from the principal accounts of the constitutional issues raised by the abolitionist mails. It goes unmentioned, for example, in Donna LeE Dickerson, The Conrse of Tolerance: Freedom of the Press iN 
article rescues this notable document from the obscurity into which it has unfortunately been consigned. In addition to publishing the full text of the final, corrected version, it locates Hall's report in its cultural setting and touches on its significance for American public life.

The copy of Hall's report that I have chosen to edit can be found among Hall's papers at the Park McCullough House in North Bennington, Vermont. The copy consists of a lightly edited clipping of the Intelligencer version, to which Hall appended a new introduction and conclusion as well as several hundred words of additional text. Hall presumably intended it for publication, very possibly in pamphlet form. This would explain why he took such trouble to improve on the Intelligencer version. No pamphlet version is existant, however, and there is no evidence that one was ever prepared. Hall undertook the revisions himself, signed it, dated it "April 1836," and marked it "corrected." 8

Hall's authorship of the report cannot seriously be questioned. Hall may have borrowed some ideas from like-minded Congressmen such as George N. Briggs, yet neither Briggs nor Briggs's biographer ever laid claim to the work. ${ }^{9}$ Hall took sole credit for its authorship both in the manuscript version in his personal papers and in a third-person autobiographical sketch. "In 1836, while a member of the Post Office Committee," Hall declared in this sketch, he "prepared an cxtensive minority report in opposition to the passage of a bill to suppress the circulation of mail in the Southern states of printed matter on the subject of slavery, termed 'Incendiary Publications." The resulting report, Hall added, demonstrated "the great difficulty and danger of such legislation," as well as its unconstitutionality, since the Constitution itself "conveyed no power on Congress to look into publications and prescribe what opinions should and should not be admitted into the mails." 10

Hall's report was spurred by his revulsion at the strident antiabolitionism of many of the country's leading public figures. Antiabolitionist sentiment was common during this period through the United States and had been powerfully inflamed the previous summer by a highly unusual mass mailing organized by the American Anti-Slavery Society, a small yet influential abolitionist organization based in New York City. Under

Nineteenth-Century America (New York: Greenwood Press, 1990), and William M. Wiecek, The Sources of Antislavery Constitutionalism in America, 1760-1848 (Ithaca: Comell University Press, 1977). One notable exception is Michael Kent Curtis, The Curious History of Attempts to Suppress Antislavery Speech, Press, and Petition in 1835-37, NORTHWESTERN UNIVERSITY LAW RFVIFW 89 (spring 1995): 826-827.

8. Hiland Hall, Incendiary Publications, Hiland Hall Papers.

9. William C. Richard, Great in Goodness: a Memoir of George N. Briggs (Boston, 1866).

10. Hiland Hall, Memoir, typescript, Hiland Hall Papers. 
the leadership of the evangelical merchants Lewis and Arthur Tappan and the antislavery jurist William Jay, the Anti-Slavery Society had tried to flood the slaveholding states with publications urging the immediate, uncompensated abolition of slavery.

To reach their intended audience, the abolitionists hoped to rely on the postal system. This was a risky strategy, given the well known solicitude of federal public officers for the interests of the slaveholding states. Yet, under the circumstances, it was an understandable choice. In this period, the postal system was the only institution with the necessary administrative capacity to transmit such a large volume of information over such an enormous geographical expanse and the only institution with a legal mandate broad enough-at least in theory-to circumvent the welter of state laws that would otherwise have blocked the transmission of abolitionist publications within the slaveholding states. Under federal law, postal officers were obliged to transmit every publication they received impartially, without regard to content. Had the organizers of the mass mailing tried to transmit their publications in any other way, they would soon have fallen under the jurisdiction of the states, which, everyone agreed, had the necessary authority to block their transmission. By relying on the postal system, the abolitionists hoped to circumvent this ban. 11

The abolitionists' faith in the postal system proved ill founded. Throughout the United States, postmasters joined together to prevent their publications from getting through, while angry crowds denounced their efforts in huge outdoor rallies. In New York City, Postmaster Samuel Gouverneur assured an enthusiastic public meeting that he would bar the abolitionists from entering publications at the New York post office that were bound for the slaveholding states, even though Gouverneur acknowledged that such a policy was illegal under federal law. 12 Similar public meetings were held in many other northern cities, often with the implicit sanction of the Democratic party, which was eager to conciliate its many southern supporters. 13

In Charleston, South Carolina, a group of men broke into the post office, commandeered the abolitionist publications, and burned them in the public square. The Charleston episode was highly unusual. Yet it illustrated the magnitude of the threat that the abolitionists posed. Should the federal government permit the mass mailing to continue, warned Charleston postmaster Alfred Huger, it would encourage indiscriminate attacks on the mail by roving bands of poor whites, thereby cndangering the enormous volume of commercial correspondence that merchants routinely transmitted through the mail. 14 Huger's fcars were echoed by anti-

11. For a more extended discussion of this controversy, see RICHARD R. John, Spreading The News: The American Postal System from Franki. IN to Morse (Cambridge: Harvard University Press, 1995), 257-280.

12. New York Journal of Commerce, cited in Chari.eston CoURIER, 3 September 1835.

13. John, SPREAding THE NEWs, 276-277.

14. JOHN, SPREADING THE NEWS, 266. 
slavery advocates. "Under a plea of danger to the institution of slavery," wrote the antislavery editor of the New-York American, "we have seen the U. S. Post Office at Charleston broken open by force, its packages assorted, and those deemed obnoxious-though as much under the protection of the law as any letter containing bank notes-taken out, and publicly, upon full notice, and without interruption from the magistracy of the place, burn."15 Others warned about the dangers of a slave rebellion. From their standpoint, the abolitionist publications were literally "incendiary" in the sense that they threatened to spark a conflagration that could put the white population at risk.

The strident antiabolitionism of New York postmaster Gouverneur was echoed by many other federal public officers. In his annual message to Congress, President Andrew Jackson excoriated the abolitionists as crazed fanatics and urged the passage of federal legislation prohibiting the transmission into the South of "incendiary publications intended to instigate the slaves to insurrection." 16 Within Congress, Jackson's sentiments were championed by fellow Tennessean Ebcnezer Shiclds, who urged the passage of legislation banning anyone from admitting "incendiary" literature into the mail. Henceforth, Shields decreed, Congress should prohibit as incendiary any handbill, newspaper, pamphlet, print, picture, or document that had "the intent to instigate or excite the slaves [of] any of the said slaveholding States or territories to insurrection or domestic violence." 17

Jackson was also seconded by Postmaster General Amos Kendall. Unlike Shields, Kendall refrained from making any specific policy recommendations. Kendall did, however, propose a number of rationales for whatever restrictive legislation Congress might choose to enact. Congress might, Kendall proposed, treat the mass mailing as a violation of international law. It was a mistake, Kendall explained, to assume that the "right of free discussion" that individuals enjoyed in the states where they lived could be extended to the entire country, "unless it be obtained by compact or treaty." Kendall also proposed a constitutional rationale for the proposed suppression. Since, Kendall posited, the abolitionist publications might incite the slaves to rebel, their suppression could be justified by the constitutional provision that empowered the federal government to intervene in the internal affairs of the states should "domestic violence" threaten the public peace. 18

15. Liberty of the Press, New-York American, cuuntry edition, 29 April 1836.

16. Andrew Jackson, Seventh Annual Message, 7 Deccmber 1835, in House Miscellaneous Document no. 210, 53rd Cong. 2nd sess., in Compilation of the Messages and Papers of the Presidents, 1789-1897, ED. J. D. Richardson (Washington: Govemment Printing Office, 1907), 3:175.

17. H.R. 245, 24th Cong., 1st sess., 19 May 1836, 29-30.

18. Amos Kendall, Report of the Postmaster General, 24th Cong., 1st sess., 1835, S. Doc. No. 1, scrial 279, 398-399. 
By far the most elaborate critique of the mass mailing was put forth in a celebrated report by the influential South Carolina Senator John C. Calhoun. In his report, Calhoun urged Congress to pass legislation to require postmasters in the nonslaveholding states to obey those southern state laws that declared the transmission of abolitionist publications illegal.19 Authority for the restrictive legislation, Calhoun posited, derived not from the federal Constitution, but rather from state law, which the federal government had an obligation to reinforce. Calhoun was particularly critical of Jackson's proposal, which he derided as an unconstitutional arrogation of power.

Calhoun's critique of Jackson is often interpreted in a narrowly partisan way. Calhoun was ambitious for the presidency, or so it is argued, and, thus, took such a brazenly proslavery position in a calculated attempt to consolidate his popular support in the South. Yet from Hall's standpoint, Calhoun's proposal differed little from Jackson's. Both sought federal legislation to deny the abolitionists the use of the mails; their quarrel focused merely on how this ban was to be justified. Jackson looked to federal law; Calhoun to the states.

Jackson, Shields, Kendall, and Calhoun may have disagreed as to the most appropriate means to stop the abolitionists, yet all agreed that the federal government had an obligation to act. Some kind of restrictive legislation also had the support of a majority of the House Committee on the Post Office and Post Roads, which voted 6 to 3 in favor of the constitutionality of federal involvement. 20 The House majority may have felt it impossible to choose between Jackson and Calhoun, yet it had no quarrel with the principle of government control. The major disagreement involved whether the Constitution empowered Congress to act on its own or whether Congress derived its authority from legislation that had alrcady been passed by the statcs. For many, the question seemed decidedly reminiscent of the recent nullification controversy, with Jackson once again championing the sovereignty of the federal government and Calhoun the rights of the states.

Hall intended his report as a response to these proposals. From his standpoint, the quarrel between Jackson and Calhoun was far less significant than their shared determination to impose on the abolitionists some kind of government control. This Hall rejected outright.

Hall divided his report into two parts. In the first part, he criticized the various legislative proposals on practical grounds. In the second part, he considered the broader constitutional issues that these proposals raised. Hall grouped the various legislative proposals into four categories: proposals that required the licensing of all publications to be admitted in the

19. John C. Calhoun, Report from the Select Committee on the Circulation of Incendiary Publications, 4 February 1836, in Robert I. Meriwethfor fr al.., eds., The Papers of John C. Calhoun (Columbia: Universily of South Carolina Press, 1959), 13: 53-67.

20. Register of Debates, 24th Cong., 1st sess., 25 March 1836, 2945. 
mail and the exclusion of those that Congress deemed unmailable; proposals that prohibited public officers and postal patrons from transmitting publications illegal under state law; proposals that confined this prohibition to public officers; and proposals that banned the transmission of "incendiary" publications outright. The first two of these proposals were hypothetical; the third was Calhoun's; the fourth, Jackson's.

Hall considered each of these proposals in turn. The first proposal, he observed, would necessarily require the establishment of an administrative body to inspect every publication prior to its admission into the mail. This innovation, Hall predicted, would never be sanctioned by public opinion. After all, such a law would transfer the property rights of the publisher from a jury of peers to "the summary discretion" of any one of the "many thousand individuals" whom the government entrusted with its enforcement, including, presumably, countless village postmasters at country crossroads throughout the United States. The establishment of such a "tribunal," Hall declared, was so utterly foreign to "all the preconceived opinions of the People of this country" that he could not seriously believe it would ever be enacted. Indeed, there is no rccord that such a draconian measure was ever proposed.

Hall regarded the second and third proposals as far more formidable and devoted to them the bulk of his report. He focused his attack on rebutting their shared assumption that the authority for the proposed restrictions could be derived not from the federal Constitution, but, rather, from state law. This premise, of course, was the linchpin of Calhoun's critique of Jackson. Hall never quarteled with the proposition that the states had the right to restrict the transmission of information within their borders. But he saw no reason why the federal government should be implicated in the enforcement of these restrictions. "A State cannot call on Congress," Hall declared, "to make laws for the punishment of offenses against State authority...It is not in the power of Congress to exalt offenses against the States into offenses against the General Government." Hall also challenged Kendall's characterization of the mass mailing as a violation of international law and Kendall's attempt to rationalize the restrictive legislation as an application of the constitutional provision guaranteeing the states protection against domestic violence.

Hall devoted much attention to the practical problems that the federal enforcement of state laws would pose for federal administrators. Should Congress agree, as a matter of principle, that the federal government had an obligation to enforce state laws regarding abolitionist publications, Hall did not see why this prohibition might not be extended to publications on other controversial topics. And if it were, Hall did not see how federal administrators could remain sufficiently well informed about the various restrictions. "One State might prohibit the dissemination of the Catholic doctrine," Hall speculated, "another, that of the Protestant; one that of one political sentiment, and another that of its opposite." Even more disturbing were the kinds of information that Congress might find itself obliged to restrict. Should the states have their way, Congress might 
soon find itself banning the transmission of publications dealing with the slavery question; those advocating the religious beliefs of the Arminians, the Calvinists, or the Unitarians; those maintaining controversial political positions like nullification; and even those challenging the principles of the administration or the conduct of its officers. Most troubling of all, such a ban might preclude certain key public issues from ever entering the public arena, "bandaging the eyes" of the electorate, making it impossible to legislate responsibly, and thwarting majority rule.

Similar practical considerations, Hall believed, doomed the fourth proposal, even though this proposal was confined to the operations of the federal government, and even though it focused specifically on publications intended to incite the slaves to rebel. Once Congress established the precedent that the government could restrict the transmission of publications through the mail, Hall observed, it was impossible to know how this principle might come to be applied.

Having critiqued the various proposals on practical grounds, Hall next turned to their constitutionality. Here, too, he found much to object to. Nowhere in the Constitution, Hall argued, did the people of the United States grant Congress the power to restrict the content of information sent through the mail. "All modes of abridgment whatever are excluded," Hall wrote, "whether by the establishment of a censorship, the imposition of punishments, a tax on the promulgation of obnoxious opinions, or by any other means which can be devised to give a legitimate preference, either in publication of circulation, to one sentiment emanating from the press, over that of another... It was not against particular forms of legislation, but to secure the substance of the freedom of the press, that the clause was made a part of the Constitution."

Restrictions on the postal system were particularly pernicious, given the legal ban on outside competition. Under the federal Constitution, Hall obscrved, the federal government possessed an exclusive power over the postal system, giving it "entire control" of the transmission of information throughout the United States: "Neither a State nor individuals, in opposition to the will of Congress, can establish or carry on the business of such circulation." Should, therefore, Congress restrict the transmission of publications through the mail, this would not only abridge the freedom of the press, but destroy it: "No periodical in the country which was prohibited a mail circulation could compete with its antagonist publication to which that privilege was allowed with the smallest hope of success."

The principal exceptions that Hall recognized included materials that clearly impeded the "safe and expeditious dissemination of information from one part of the country to another." Among these were articles "calculatcd to produce mischief or crime" such as counterfeit checks, drafts, and bank notes. Though Hall never said so explicitly, he strongly implied that the prohibition of these items from the mail would not come into conflict with "any of the prohibitory clauses of the Constitution." Hall also acknowledged that circumstances could arise where it might prove necessary for Congress to prohibit the circulation of "particular classes of pub- 
lications," including pamphlets, magazines, and newspapers. In this way, he left Congress the necessary flexibility to prevent postal officers from being deluged with thousands of bulky items that would slow the movement of business correspondence, which, in this period, was the principal source of postal revenue. 21 At no point, however, did Hall qualify his basic contention that Congress lacked the authority to block the transmission of publications advocating some specific idea.

Hall conceded that he might rest his argument here, having demonstrated that any restrictions that Congress might enact would be not only impractical but also unconstitutional. But he went still further and considered possible historical precedents for the proposed law. The best known of these precedents was the Sedition Act of 1798, a short-lived piece of federal legislation that permitted federal officials to punish editors who published information that falsely libeled the federal government. Since it had long been assumed that this legislation was unconstitutional, Hall had little trouble demonstrating that it failed to furnish a precedent for the current proposals. "If it be said," Hall declared in summarizing his position, "that the publications which we are now called upon to suppress are really and truly dangerous, seditious, and incendiary, then the minority say they are really and truly some of the precise publications against which it was designed by the Constitution that Congress should have no power to legislate."

Hall's argument rested squarely on his bold and uncompromising interpretation of the Bill of Rights. Not since Thomas Jefferson and James Madison had opposed the Sedition Act in the Kentucky and Virginia Resolutions as an unconstitutional aggrandizement of federal power had a public figure so emphatically denied the right of the federal government to restrict the freedom of the press. Yet in one respect, Hall went further than these earlier champions of the first amendment. Jefferson and Madison had confined their critique to legislation that protected the federal government from editorial assault. Hall, in contrast, opposed federal legislation aimed at publications objectionable for reasons that had nothing to do with their position on national public affairs.

It would be anachronistic to hail Hall's report as a precursor to the modern libertarian defense of a free press. Unlike modern libertarians, Hall freely conceded that the individual states retained a broad measure of authority to censor publications that they deemed injurious. While such a concession might seem strange today, it was taken-for-granted in the early republic that powers prohibited to the federal government might well be reserved to the states. Modern libertarians champion the rights of individual expression and challenge the authority of legally constituted entities such as states, cities, or towns. Hall took these restrictions for granted and never questioned the right of these entities to regulate individual expression. "Upon the subject of the press," Hall explained, "the legislation of

21. On the importance of commercial correspondence to postal revenuc, see JoHN, SPREADING THE NEWS, 157-158. 
the States is only limited by their State Constitutions, and those Constitutions are subject to no control by the General Government so long as they remain 'republican in form.' It is believed that the Constitutions of most, if not all, of the States contain some restrictions on the power of their Legislatures over the press, but, without such restrictions, the power would be full and complete, even to the establishment of a censorship."

Yet the crux of Hall's argument focused less on these state and local prerogatives than on the fundamental guarantees enshrined in the first amendment. In this regard, Hall's position was decidedly more expansive than that of Jefferson, Madison, and the other participants in the earlier debate over the Sedition Act.22 Though Jefferson had eloquently championed the right to free expression in the Kentucky Resolves, his position was grounded in his solicitude for states' rights. Madison's position in the Virginia Resolves was more complicated. Yet he had long harbored misgivings about the unfettered transmission of information throughout the length and breadth of the country. 23 Indeed, the condernnation of the Sedition Act during the 1790 s bore a certain curious resemblance to the antiabolitionist assault upon the American Anti-Slavery Society in the 1830 s. In both controversies, the protection of states' rights-and not the defense of the first amendment-was the most immediate concern. Had Jefferson been alive in 1836 , there is good reason to suspect that he might have opposed Hall's report, and, perhaps, even supported the suppression by the federal government of the abolitionist mails. 24

Hall was by no means the only public figure to question the propriety of the proposed legislation. In New York, maverick journalist William Leggett editorialized against any change in the status quo, while in New England, an anonymous pamphleteer published Freedom's Defense, a sixteen-page attack on Calhoun. 25 The de facto suppression of the abolition-

22. See, for example, James Roger Sharp, american Politics in the Early Republic: The New nation in Crisis (New Haven: Yale University Press, 1993), 187-207, esp. 206-207.

23. On this point, see John, Spreading THE News, 62-63.

24. For a more extended discussion of the public debate over the frecdom of the press in the 1830 s, see Curtis, Curious History; Dickerson Course of Tolerance; Timothy W. Gleason, The Watchdog Concept: Thie Press and the Courts in Nineteenth-Century Amfrica (Ames: Iowa State University Press, 1990); Margaret A. Blanchard, Filling in the Void: Speech and Press in State Courts Prior to Gillow, in Bill F. Chamberlin and Charlene. J. Brown, hid., The First amendment Reconsidered: New Perspectives on the Meaning of Freedom of Speech and Press (New York: Longman, 1982), 14-59: Walter Berns, The First amendment and the Future of American Democracy (New York: Basic Books, 1979), 121-124; and Berns, Freedom of the Press and the Alien and Sedition Laws: A Reappraisal, Supreme Court Review, 9 (1970): 109-159.

25. William Leggett, a Collection of the Political Writings of William Leggett, 2 vols., ed. Theodore Sedgwick (New York: Taylor \& Dodd, 1840); "Cincinnatus" Freedom's Defence: Or, a Candid Examination of Mr. Calhoun's Report on the 
ists aroused concern as well. Particularly offensive to many Americans was Postmaster General Kendall's refusal to discipline subordinates like New York Postmaster Gouverneur who restricted the transmission of abolitionist publications on his own authority. Kendall's conduct "stirred thousands to action," observed one keen observer of the contemporary scene, who had "never sympathized with the Abolitionists and who were even opposed to their movements." 26

Hall was the first public figure to bring these concerns before Congress. "Not a word, not a whisper" had been uttered in Congress in opposition to the proposed legislation, Hall reminded his colleagues when he tried to present his report on March 25.27 Hall found particularly galling the willingness of Congress to publish Calhoun's report in an edition of 5,000 copies, since that virtually guaranteed it a wide hearing among the public-at-large. 28 The surviving transcriptions of the congressional debates confirm Hall's concerns. Not until after Hall had made his report would Massachusetts Senators Daniel Webster and John Davis challenge the proposed restrictions on constitutional grounds. Though neither alluded to Hall's report directly, it is entirely possible that Hall emboldened them to take this stand. Yet they could have just as easily have been echoing Calhoun, who struck a similas note in his defense of federal legislation reinforcing the laws of the states.

It is hard to know how widely read Hall's report was among the public-at-large. Critics like Congressmen Ebenezer Shields taunted him for having sent it "out to the world," while Hall himself reported matter-offactly that it was printed in "many of the leading newspapers of the North." 29 Shields and Hall surely exaggerated. Few newspapers reprinted Hall's report in Boston or New York City, two cities well known as centers of antislavery agitation. 30 One exception was the country edition of the New-York American, a New York City based newspaper edited by antislavery activist Charles King. King reprinted Hall's report in its entirety in late April in two successive issues. Preceding the second installment was a notable editorial, almost certainly written by King himself, on "The Liberty of the Press." After a brief survey of the abolitionist mails controversy, the editorialist turned to Hall's report, which he termed

Freedom OF THE PRESS (Worcestcr: Dorr, Howland \& Co., 1836). Though this pamphlet was long attributed to William Plumer, Plumer's biographer cogently argues that this is highly unlikely. LynN W. Turner, William Plumer of New HampShire, 1759-1850 (Chapel Hill: University of North Carolina Press, 1962), 339.

26. Nathan Sargent, Public Men and Events from the Commencement of Mr. MONROE's ADMinistration, in 1817, to the Close of Mr. Fillmore's Administration, in 1853 (Philadelphia: J.B. Lippincott \& Co., 1875), 2:61.

27. Register of Debates, 24th Cong., 1st sess., 25 Match 1836, 2945.

28. Hiland Hall, Memoir.

29. Hiland Hall, Memoir; Rfgister of Debates, 24th Cong., lst sess., 20 May 1836, 3795 .

30. This generalization is based on a survey of the files of Boston and Ncw York City newspapers in the Library of Congress. 
"calm, able, and, as appears to us, conclusive." 31

King's support for Hall demonstrates that, as Hail insisted, his report did indeed circulate among the public-at-large. But it would be a mistake to exaggerate its influence. King was, after all, a highly atypical figure. Widely derided for his antislavery views-which were sometimes linked with those of his father, the Federalist statesman Rufus King-he could have been expected to find in Hall a kindred spirit. 32

Had Hall's report been widely reprinted it seems unlikely that it would have remained so obscure. Never issued as a separate pamphlet, it was rarely alluded to in Congress. Nor did it find its way into Niles's Weekly Register, a newspaper on which many country editors relied for their news. If it had, it would almost certainly have been widely reprinted in the North. Lacking Niles's endorsement, it was quickly forgotten by everyone other than committed radicals like King. Little wonder, then, that, with few exceptions, historians of the period have overlooked it altogether.

Within Congress, the influence of Hall's report is more difficult to gauge. To be sure, Hall won the main point. Neither in 1836, nor at any subsequent date, and notwithstanding the best cfforts of Jackson and Calhoun, did Congress pass legislation to restrict the transmission of abolitionist publications in the mail. Hall firmly believed that if he could impress upon his congressional colleagues the administrative ramifications of the proposed legislation, they would ultimately oppose it. Had no one spoken up in opposition to the proposed restriction, it seems more likely that some restrictive legislation would have found its way into law. But it would be a mistake to conclude that the abolitionists won the day. On the contrary, they were effectively stymied by a variety of administrative procedures that, in conjunction with state and local law, effectively nullified the antidiscriminatory provisions that Congress ultimately reaffirmed.

It is entirely conceivable that Hall played a major role in blocking Congress from passing legislation to restrict the transmission of abolitionist publications in the mail. Hall followed postal affairs closely and had a keen appetite for the fine points of the law. In addition, as a member of the House post office committcc, he played a major role in the drafting of the Post Office Act of 1836 , the first major picce of postal legislation to be passed following the abolitionist mails controversy.

Hall's role in the passagc of the Post Office Act of 1836 is worth highlighting, since, contrary to a widespread impression, this major piece of legislation was the brainchild not of Jacksonian administrators such as Amos Kendall but, rather, of a loose coalition of anti-Jacksonian legislators that included, in addition to Hall, Ohio Congressmen Elisha Whittlesey, and Ohio Senator Thomas Ewing. ${ }^{33}$ Hall's involvement in this legislation is particularly notable since, in section 32 , Congress reaf-

31. New-York AmERICAN, country edition, 26, 29 April 1836

32. See, for example, Charleston Soutilern Patriot, 19 August 1835, 2 September 1835.

33. Henry D. Hall, Memoir of Hon. Hiland Hall, 12. On the passage of the Post Office Act of 1836, see JOHN, SPRFADING THF. NF:WS, 247-248. 
firmed its traditional commitment to the unrestricted transmission of information, declaring that postmasters who "unlawfully" delayed the transmission of letters, newspapers, or parcels would be subject to fine and arrest. 34

The inclusion of this provision in the first major piece of postal legislation that Congress enacted following the abolitionist mails controversy has long puzzled legal historians, who have argued, quite plausibly, that given the overwhelming support for some kind of restrictive legislation, section 32 must have been added in a "fit of legislative absence of mind." 35 Could, one wonders, it have been the work of an antislavery activist like Hall?

No hard evidence has come to light that would link Hall to section 32. One thing is certain. It was most certainly not appended to the post office bill as a result of Hall's report. The clause, after all, had been added to the post office bill several months before Hall got up to speak. ${ }^{36}$ In addition, it is by no means self evident, as is sometimes assumed, that this clause had been framed with specific reference to the abolitionist mails. 37 The partisan manipulation of campaign literature was a major issue in this period and 1836 was an election year. Thus, it is entirely conceivable that section 32 had been intended not to protect the abolitionists, but, rather, to discourage Jackson-appointed postmasters from blocking the transmission of campaign literature hostile to the party in power.

\section{***}

Whether or not Hall had a palpable influence on the course of events, his report provides a valuable perspective on certain features of American public life in the generation following the adoption of the federal Constitution. Most obviously, it reminds us of the enormous significance that public figures like Hall placed on the possibilities of public debate. Hall recognized that his position was apt to be viewed as controversial. Yet he firmly believed that, once southern Congressmen agitated the slavery issue, antislavery advocates had a moral obligation to speak their mind. The slavery issue, as he explained to a Vermont constituent shortly before he made his report, "has been gone into, incited and in fact forced upon the House by the South... and now that the subject is up, the ice broken, and the subject becomes a matter of free and unrestrained conversation, I am willing the debate should be continucd until all possible light is thrown upon the subject; not doubting in the heart that good will grow of it." In the end, he predicted, public discussion of the issue would tend to "bring the North and the South nearer together, and allay rather

34. U. S. Statutes at Large 5 (1836): 87.

35. Wiecek, Antislavery Constitutionalism, 177.

36. H.R. 245, 24th Cong., 1st sess., 28 January $1836,17$.

37. On this point, I am indebted to a series of conversations with Michael Kent Curtis. 
than increase the jesiousies existing on this matter." 38

Equally notable was Hall's hostility toward the growing power of the federal government. Like many northern Whigs, Hall deplored the proslavery tilt of federal public policy under the Jacksonians and hoped to check this trend. Hall found it particularly troubling that so few southern Whigs joined him in raising questions about the constitutionality of legislation that scemed so surprisingly similar to the hated Sedition Act. How could men who claimed to be the political heirs of Jefferson and Madison, Hall admonished Congress, prove so quick to abandon the "great landmarks of the constitution established by their fathers"?39 By framing the issue in this way - as a challenge not only to civil liberties, but also to traditional notions of the balance of power between the federal government and the states-Hall gave voice to the emerging conviction that the federal government had bcen captured by a malignant "slave power" intent on destroying the liberties of freemen throughout the United States. By the 1850 s, this conviction would become a key tenet of the Republican party, to which, appropriately, Hall transferred his allegiance following the collapse of the Whigs.

Hall's skepticism toward centralized power extended well beyond his apprehensions regarding recent political developments in the South. Like so many political outsiders in the early republic, Hall was a Baptist, and, as such, highly sensitive to the dangers that restrictive legislation posed to those holding unpopular beliefs. 40 Though there is little evidence that Hall was particularly devout, he well understood how to deploy the highly charged rhetoric of evangelical anticlericalism for political effect. Hall's report, for example, contained several pointed references to the evils of state-sponsored religious persecution and the absurdity of all attempts to resolve religious issues by legislative fiat. Indeed, it would hardly be an exaggeration to suggest that, by treating the constitutional guarantee of a free press as a sacred text, Hall went far toward investing the Bill of Rights with the moral authority of the Ten Commandments.

Nowhere was Hall's religiosity more self evident than in his discussion of the similarities between the abolitionist mails controversy and the controversy over the Sabbath mails. Should Congress restrict the transmission of abolitionist publications, Hall warned, this would be analogous to permitting the Sabbatarians to stop the transmission of the mails on every seventh day. To make his case, Hall cited the celebrated reports on the Sabbath mails of Kentucky Congressman Richard M. Johnson. ${ }^{41}$ Hall's allusion to Johnson's reports had obvious political import, since Johnson was a popular statesmen and, at the time Hall made his report,

38. Hiland Hall to David Rohertson, 24 January 1836, Hiland Halt Papers.

39. Register of Debates, 24th Cong., 1st sess., 20 May 1836, 3809.

40. It is interesting to note George N. Briggs was also a Baptist, a circumstance that may well have contributed to his willingness to add his signature to Hall's report.

41. For a more extended discussion of the influence of Johnson's reports, see JoHN, SPREADING THE NEWS, 198-200; 201-202. 
the Democratic vice presidential nominee. Hall's allusion struck a religious note as well, since Johnson's reports, like Hall's, were suffused with the evangelical anticlericalism that was a hallmark of Baptist sermonizing. In fact, though it was not widely known at the time, Johnson's reports had been written not by Johnson but by the well known Washington, D. C., Baptist minister Obadiah Brown. 42

Hall was plainly impressed with Johnson's logic, and, at a number of points, echoed his sentiments almost word-for-word. In one passage, Hall cribbed a phrase from one of Johnson's reports directly, claiming that, should Congress act, it would " involve Congress in a legislative decision of a religious controversy"." 43 Hall found this analogy compelling because he regarded both antiabolitionists and Sabbatarians as powerful lobbies intent on using the government in order to dominate the public agenda. To buttress his argument, Hall speculated about how Congress might respond had the Sabbatarians sought not only to stop the transmission of the mail on every seventh day, but also to urge the passage of legislation banning the transmission of publications that questioned the divinity of the Sabbath. Had the Sabbatarians advanced such a notion, Hall hypothesized, the congressional post office committees would surely have lambasted them for their assault upon the freedom of the press. And if Congress had launched such an assault, Hall predicted, the "judgment of the country" would have been no less "uniform and conclusive" than it had been in the controversy over the Sabbath mails.

The similarities between Hall's report and Johnson's may help to explain why Hall's congressional colleagues proved so determined to prevent him from being heard. Had Hall's report been widely reprinted, it could conceivably have become a rallying cry among anticlerical evangelicals-Baptists, Disciples of Christ, and perhaps even Methodists-at least in the nonslaveholding states. Richard M. Johnson's reports on the Sabbath mails had pointedly demonstrated how effective anticlerical evangelicalism could bc as a political tool. Given the salience of religious rhetoric to the politics of the day, Hall's colleagues had good reason to do all they could to block him from taking his case to the public-at-large.

Religious conviction, while important, was by no means the only source of Hall's ideas. Hall was also plainly inspired by the example that Jefferson and Madison had set during the controversy over the Sedition Act. Purely political considerations may have shaped his conduct as well. It seems highly unlikely that Hall would have spoken out so forthrightly had he not been representing a state so geographically isolated from the South, or so notoriously sympathetic to the antislavery appeal. Intcrestingly, the Vermont legislature picked up Hall's call and challenged the antiabolitionists directly. "Neither Congress nor the state gov-

42. John, SPREADING THE NEwS, 199.

43. The source of this quotation is Richard M. Johnson, Sunday Mail, H.R. Rep. 271, 21st Cong., ist sess., p. 2 . Hall misquoted Johnson stightly. The original read: "constitute a legislative decision of a religious controversy." 
ernments"-declared the legislature in November 1836, expressing a sentiment that went even further than Hall-"have any constitutional right to abridge the free expression of opinions, or the transmission of them through the public mail." 44 In the aftermath of the abolitionist mails controversy, no other state legislature defended the freedom of the press in such an unequivocal way.

Yet had Hall not invested the constitutional guarantee of a free press with the authority of a sacred text, it seems far less likely that he would have been emboldened to speak his mind. For Hall, as for so many Americans in the early republic, evangelical Protestantism provided a compelling explanatory framework for making sense of the events of the day. 45 "The People of the United States"-Hall declared with the evangelical intensity of a true believer-"never intended that the Government of the Union should exercise over the press the power of discriminating between true and erroneous opinions, of determining that this sentiment was patriotic, that seditious and incendiary, and therefore wisely prohibitcd Congress all power over the subject." Like an Old Testament prophet, Hall was unwavering in his beliefs, unmoved by majority opinion, and determined to be heard.

It should, thus, be evident that the public debate over the abolitionist mails involved far more than a narrowly partisan quarrel over how the abolitionists might best be suppressed. Equally important was Hall's principled defense of the freedom of the press and Hall's own determined cfforts to uphold the right of free discussion by bringing his ideas before the public-at-large. This edition of Hall's report makes it possible to appreciate the radicalism of Hall's alternative to the various political expedients that were favored by Jackson, Kendall, and Calhoun. No less importantly, it brings into public view for the first time in a century and a half one of most unequivocal, elaborate, and compclling defenses of the freedom of the press to have been prepared by a major public figure in the early republic.

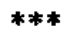

The minority of the committee on the Post Office and Post Roads, to whom was referred that part of the President's Message which relates to "the circulation in the Southern states, through the mail, of incendiary

44. Acts ... of ... Vermont .. 1836 (n. p., 1836). The Vermont resolution could conceivably have been influenced by Hall's report, though it went considerably further than he did in challenging the authority of the states. Indeed, it was one of the most radical statements on this subject to have heen issued by any public body during the abolitionist mails controversy. WiecEK, ANTISLAVERy Constitutionalism, 181-182.

45. For a more general discussion of the contributions of evangelical Protestantism to political radicalism, sce Gordon S. WoOd, The Radicalism of the AMERICAN Revolution (New York: Alfred A. Knopf, 1991) and Nathan O. Hatch, The Democratization of American Christianity (New Haven: Yale University Press, 1989). 
publications" having come to a conclusion adverse to any legislation on the subject, respectfully ask leave to submit their views to the House.

In considering the important subject submitted to the committee, the minority have not undertaken to ascertain what remedies may be afforded by State legislation for the evils complained of in the message, or to make any particular examination of the character and tendency of the publications against which the legislation of this Government is recommended. Taking it for granted that, in the opinion of Congress, the publications specified in the message have the dangerous tendency stated by the President, they proceed, at once, to inquire into the duties and powers of this Government in regard to their mail circulation.

Supposing the interposition of no constitutional obstacle, either of four modes of legislation might be adopted by Congress, to restrain the mail circulation of these publications.

1. Officers might be appointed by the Government to inspect and license all publications before they should be allowed admission into the mail, with power to exclude those of such character as Congress might designate.

2. Congress might adopt the legislation of the States as the basis of its legislation; and provide that it should be an offense against the United States for any person to send through the mail into any State any publication the circulation of which was prohibited by the laws of such State.

3. Congress, retaining the State laws as the basis of its legislation, might confine the penalties of its law to the officers of the General Government, and provide for the punishment of such postmasters and other persons employed by the Post Office Department as should, knowingly, transmit through the mail any publications prohibited by the laws of the State into which they were directed.

4. Congress might make it an offense against the United States, punishable before the Federal Courts, for any person to send through the mail, into any of the slaveholding States, any publications which Congress might specify, as having a tendency to excite the slaves to insurrection.

The minority are not aware that any other direct modes of legislation by Congress have been suggested, and, for the present, waiving the question of their constitutionality, they will proceed to examine the nature and character of each in its order.

The first mode, that of the establishment of a censorship over all publications, for which the benefit of a mail circulation was desired must necessarily operate with extreme harshness. It is obvious that publications could not be licensed from an examination of their titles, for those might be no index to their contents; and political newspapers or literary magazines, mostly filled with other matter, might contain brief articles obnoxious to the law, rendering their circulation inadmissiblc. In order to make the law effectual, a censor must be appointed in the vicinity of every printing press, whose duty it would be to examine every number of every periodical, and every edition of all other publications, for which a mail circulation was sought, and certify their fitness for such circulation to the 
postmasters; or the postmasters themselves must be erected into censors, with power to break the envelopes of all packages deposited in their respective offices, to examine their contents, and either reseal and transmit them, or suppress their circulation, as their judgments should determine them to be in compliance with, or a violation of, the law. One of the obvious legal effects of this mode of legislation would be to transfer the power of determining a publisher's right to circulate, and also his right of property in the publications, from a jury of his peers to the summary discretion of any one of many thousand individuals. The medium of mail circulation has become so useful and important to the press of the country, and would be so trammeled and obstructed by the previous submission of all matters to be transmitted to the tribunal of a licenser, that this species of censorship could be scarcely less exceptionable and oppressive than a censorship that should extend to the restraint of the actual printing of publications. On the whole, a law of this description would be in such direct opposition to all the preconceived opinions of the People of this country, so abhorrent to their notions of the principles of civil liberty, and so utterly destructive of the freedom of the press, that the undersigned will not permit themselves seriously to apprehend that, under any possible circumstances, such a law can ever find a place on our statute book. They, therefore, dismiss this branch of the subject, without further comment.

The second mode of legislation, that of prohibiting the circulation by mail of such publications as the States shall prohibit, being founded on the principles set forth in the report of the Postmaster General, and having also received countenance from other respectable sources, requires a more thorough examination.

It is argued by the Postmaster General, that as Congress, by the fourth section of the fourth article of the Constitution, is bound to protect thc States, "on application of the Legislature, or the Executive (when the Legislature cannot be convened,) from domestic violence," Congress is consequently bound to withhold the use of its mails for the circulation of such publications as tend to excite violence in the States. The constitutional question involved in this argument will be examined hereafter; our first object being to ascertain the extent of this obligation on the General Government, supposing one to exist, and to inquire into the manner in which it is to be carried into effect. The particular case which induced the argument of the Postmaster General is, the circulation of publications which are alleged to have a tendency to excite the slaves to insurrection; but his language is general, applying to all publications; and it is obvious that, if there be any foundation for the argument, it must reach all publications which any Statc may conceive tend to instigate revolt from its authorities. If one State has a right to call on Congress to enact laws to prevent the effect of a mail circulation of publications within its limits, any other State has the same right; and if the judgment of one State is to be received as evidence of the cvil tendency of particular publications, the judgment of every other State must have the same force, and impose the same obligation on Congress. A statute, therefore, founded on this princi- 
ple, would provide that it should be an offense against the United States for any person to send through the mail into any State any publication the circulation of which might be prohibited by the laws of such State.

A statute of this description would not only punish the citizen of Massachusetts before the federal court in his State for sending publications by mail on the subject of slavery into Georgia, but would also punish the citizen of Georgia, before the federal court in his State, for sending a publication on any subject into Massachusetts, that subject, whatever it might be, having previously come under the interdict of the law of Massachusetts. Nor would it limit the extent of the operation of this statute to provide that the law of the State prohibiting the circulation of publications should not be incompatible with the Constitution and the laws of the United States. For it is to be observed that, although the Constitution of the United States prohibits Congress from making any law "abridging the freedom of speech, or of the press," yet it contains no such prohibition on the States. Upon the subject of the press the legislation of the States is only limited by their State Constitutions, and those Constitutions are subject to no control by the General Government so long as they remain "republican in form." It is believed that the Constitutions of most, it not all, of the States contain some restrictions on the power of their Legislatures over the press, but, without such restrictions, the power would be full and complete, even to the establishment of a censorship. It is not perceived that such a power, alarming as might be its exercise, would be an infringement of the Constitution of the United States, or that the Government of the Union could exert over it any legal supervision. The Constitutions which now contain restrictions are liable to amendment, and may be remodelled to answer any object which the People of any State may, for the time being, desire to accomplish. A law, therefore, made in conformity with the principle assumed by the Postmaster General, would be limited in its operation only by the will of the People of each individual State; the will of the People of any one State serving to determine what publications it should be criminal for the citizens of every other State to send into that State by mail. In relation to publications on the subject of slavery, one State might enact that it should be unlawful to circulate such publications only as had a manifest tendency to excite the slaves to insurrection; another, with the same declared object in view, might extend the prohibition to all publications on the subject of slavery; a third might confine its prohibitions to newspapers and small periodicals; a fourth might exclude the larger reviews and pamphlets; and a fifth might except from its prohibition the annual messages of the Governors of the several States, and speeches in Congress, while a sixth might include them. But the operation of the law would extend to all sentiments and opinions which any State might deem of dangerous tendency. One State might prohibit the dissemination of the Catholic doctrine; another, that of the Protestant; one that of one political sentiment, and another that of its opposite, and, under a law of this description, the extraordinary spectacle might be exhibited of two district courts of the United States sitting on the 
same day in two different States, one engaged in passing sentence on an individual convicted under the statute for sending by mail a publication advocating one opinion, and the other passing sentence on another individual, convicted under the same statute, for transmitting a publication of the directly opposite opinion; the one publication being, perhaps, a satisfactory and conclusive refutation of the doctrines of the other. Some of the cases enumerated may be of improbable occurrence, but they all fall within the legitimate scope of a statute founded on a supposed obligation in Congress to prohibit the mail circulation of publications offensive to the States, and are all cases for which, under such a statute, a punishment must be inflicted whenever they should happen.

This law would possess another anomalous character, for which the minority have sought in vain for an example. It would refer to the laws of a foreign jurisdiction for the definition of the crime for which it provided a punishment; to laws which never had been and never could be, legally promulgated to the accused. It is a legal maxim, ignorantia leges neminem excusat, that ignorance of the law is no excuse to the offender, but this maxim is founded on the principle that the laws are on record, open to inspection, and have also been published within the jurisdiction under which the offense is committed. No presumption can arise of the legal promulgation of the laws of a foreign Government, and yet the offender, by this statute, would be punished for their violation. He who would seek to avoid the penalties of such a statute, must, in point of fact, not only obtain a knowledge of the Constitution and laws of his own State, and of the United States, but also of the Constitutions and laws of every other State in the Union-Constitutions and laws which, together, would form a code, from the fathoming of which even a Coke or a Hargrave might well shrink, in some degree of despair. Surely, whoever, under the barbarous code of our Saxon ancestors, had sought the judgment of God in his favor by walking blindfold and barefooted amid the burning ploughshares, would be called upon to encounter a no less dangerous ordeal, in treading the legal labyrinths formed by the provisions of this statute.

But, without dwelling longer on the practical operation of a statute founded on the principles of the report of the Postmaster General, the minority will proceed to inquire whether Congress, by making State legislation the basis of its own would draw to itself any constitutional power to restrain the mail circulation of "incendiary publications." Such constitutional power is not supposed, by the argument of the Postmaster General, as the minority understand it, to be a general power in Congress over the mail circulation of such publications, but to be a limited power, depending on, and flowing from, the circumstance that the publications, in the opinion of the States, tend to excite insurrection. And the precise question now to be considered is, whether, supposing Congress to possess no general power to restrain the mail circulation of these publications, the power can be derived from the fact of their being offensive to the States. It is not denied by the minority that the measures of the States for preventing insurrection should be examined by the General Government with respect, 
and that this Government so far as its delegated powers will admit, should co-operate with the States in the execution of all their proper and necessary laws for that purpose. But the argument of the Postmaster General is in favor of a derivative power, and suppose a new substantive authority in Congress to arise from an alleged obligation to cooperate with the States in carrying their laws into effect. It supposes the existence of some power in the Constitution, which has been hitherto dormant, and which, if waked into activity, and written out at length among its articles, would read something after this manner: "Whereas it is intended by this Constitution to bind Congress to co-operate with the States in the measures they may adopt for preventing resistance to State authority; and whereas it may sometimes happen that Congress cannot render such legislative co-operation, by reason that no delegated power is found in this instrument enabling Congress to do so, or by reason that the legislation required by the States is of a character expressly forbidden by some of the prohibitory clauses of this Constitution: Now, therefore, it is hereby ordained and declared, that all State laws intended to prevent resistance to State authority shall be taken and deemed as conferring the aforesaid necessary power on Congress; and the said State laws shall also have the effect to repeal, pro tanto, all the prohibitory clauses of the Constitution which might seem to stand in the way of the aforesaid congressional legislation."

It must be apparent that nothing short of the power here stated would be effectual to confer the required authority on Congress. No argument in favor of this power can be drawn from any supposed principles of international law. For although the General Government, in respect to foreign nations, is necessarily subject to the general rules which the moral sense of mankind may have in some measure prescribed to regulate the intercourse between independent Powers, yet, in regard to the relations between the General Government and those of the States, the uncertain rules of the national code are abrogated and superseded by an instrument of Government, in which those relations are expressly pointed out and defined. Whether such derivative power exists or not, can only be determined by that instrument. The power can come from no other source than the Constitution; its existence can be tried by no other evidence. The minority have no hesitation in saying that, in their opinion; no such power is delegated by that instrument; and they have as little in declaring that no such power ought to be delegated. The prohibition of offensive publications is but one among the many means which a State may use to prevent insurrection. What dangers would arise from the exercise of a power of co-operation, riding above the prohibitory clauses of the Constitution in other cases than those of the circulation of offensive publications, it is not now necessary to inquire; though those of an alarming character might readily be stated. Even under this branch of the power, the derivative authority supposed, would enable a State combined with Congress to subvert some of the most valued provisions of the Constitution; and coupled with the obligation under which it is alleged to arise, by placing Congress and the whole People of the Union at the mercy of a State alone, would 
render the Constitution of little value.

Of the dangerous nature of this triumphant power in State laws, something may be seen by recurring to what has already been said of the extent of the supposed obligation, from which the power of Congress is sought to be deduced - an obligation which might compel Congress to prohibit the mail circulation of ail publications on any subject, whether moral, physical, religious, or political; and which, at the option of a single State, would impose on Congress the humiliating and suicidal act of aiding by its legislation in bandaging the eyes of every freeman in such State against the light of any argument it might desire to address them in favor its own just powers of government, or against any unlawful assumption of power by such State. Had the project of the statute now under consideration been the law of the land in 1832, it would have been entirely in the power of the Legislature of South Carolina, by prohibiting the circulation of the President's Proclamation, to have made the President himself, and every individual in the nation, liable to punishment before the courts of the United States, for directing to an inhabitant of that State, and placing in the mail, a single copy of that document.

To show the existence of this obligation the Postmaster General cites that article of the Constitution, which provides that Congress, under certain circumstances, shall protect the States from "domestic violence." It is to be observed, that such protection can only be given on special "application of the Legislature, or, when the Legislature cannot be convened, of the Executive of the State," and that then it is to be of an executive, not a legislative character. It is only when resistance to State authority becomes sufficiently alarming to induce the State Government to apprehend the inefficiency of its own means to suppress it, that it may demand of the General Government to furnish from its police, its army, its navy, or militia, a sufficient force to vindicate the supremacy of State authority; and such requisition, by the terms and spirit of the Constitution, must be obeyed. Instead of proving a legislative obligation on Congress, it seems to the minority that the language of this very article is almost, if not quite conclusive, to show that the framers of the Constitution intended to exclude from Congress the power to aid State legislation by legislation of its own. On any other supposition, how can their extreme caution be accounted for, of making the aid of the General Government of purely an executive character; of postponing such aid until actual violence has occurred, and then not suffering it to be given until a formal and direct application has been made, first, by the State Legislature, if practicable; if not, then from the Executive? Could the framers of this Constitution have supposed that a previous legislative obligation existed? Or rather, if they had intended to impose any such obligation, would it not, like the executive obligation, have been expressed, and the terms and conditions of its execution been equally well guarded and defined? But one answer can be given to these questions. The power of legislative aid was designed to be excluded.

Our previous notions of this branch of constitutional law are not erroneous. A State cannot call on Congress to make laws for the punishment of 
offences against State authority, as for the punishment of larceny, arson, robbery, or resistance to State process or laws. It is not in the power of Congress to exalt offences against the States into offences against the General Government. The jurisdiction of the General Government is confined to offences against its own authority, and cannot, by any process of mystification, be extend to offences against the authority of the States. And if Congress cannot within the limits of a particular State convert offences against that State into offences against the United States, equally unconstitutional would be the exercise of this power of transmutation on acts committed without the State jurisdiction. Although Congress may prescribe, and has prescribed, the mode by which the acts of the Legislature of one State may be proved in the courts of a sister State, yet Congress possesses no power to make the laws of one State the rule of action in another, and to impose within that other a punishment for their violation. When Congress has original constitutional authority over a subject, it may perhaps adopt State legislation as the basis of its own. A provision in the statute of August 7,1789, declaring that all pilots shall continue to be regulated by the laws of the respective States in which they may be, "until further legislative provision shall be made by Congress," is an example of this kind of legislation. But Congress in such case, instead of adopting, may, in its discretion, omit to recognize the State law, and supersede it by full and complete and full legislation over the whole subject.

The conclusion then to which we are drawn is, that if Congress has constitutional power to legislate for the suppression of the mail circulation of such publications as may be offensive to the States, Congress may exercise that power to the fullest extent, and can derive no constitutional aid from any reference to State laws. If Congress may pass the act under consideration, allowing the States for it to judge of the character of the publications to be prohibited, Congress may omit to delegate that power, and exercise it itself. Congress may and should, according to all the principles of legislation heretofore observed, fully define, in the act itself, the crime for which the punishment is to be inflicted. As before shown, Congress would, by this statute, commit to the several States the power of proscribing in their discretion, any and all publications, on any and all subjects. If the statute under consideration would be constitutional, it would be equally so were it a part of its provision, that no publications on the subject of slavery, none advocating the religious belief of the Arminians, the Calvinists, or the Unitarians, none maintaining the doctrines of nullification, and none impugning the principles of the Administration, or the conduct of its officers, should have the advantage of a mail circulation; for all these, and an infinite variety of other prohibitions are within the scope of the powers committed to the State Legislatures by the provisions of this act. Whether Congress has the constitutional power to pass such an act will be examined hereafter.

The minority will now proceed to notice the third proposed mode of legislation, which confines its penalties to the officers of the General Government, and provides for the punishment of postmasters and other 
persons employed by the Post Office Department for knowingly transmitting through the mail any publications prohibited by the laws of the States to which they are directed.

The constitutional power which is claimed in Congress to make this law, rests upon the same basis with that which we have just been considering. Admitting that Congress has no constitutional authority to judge of the tendency of publications, it assumes a power in Congress to act upon and carry into effect the judgment which may be formed of them by the States. That no such power exists has been already shown, and the argument will not be again repeated. But certain acts of Congress, which have been supposed to form precedents for this species of legislation, require to be noticed. It will be remembered that the question is not now whether Congress possesses the constitutional power to make this law, but whether such power can be derived from the State laws, or, in other words, whether the State laws, per se, impose an obligation, or confer a power on Congress, to punish its officers for violating them. The minority admit that if Congress possesses original constitutional power over the subject, it may so punish its officers. The friends of this measure, conceding that no such original constitutional power over "incendiary publications" exists, seek to derive it from the authority of State legislation. In favor of this derivative power, the act of the 28th of February, 1803, entitled "An act to prevent the importation of certain persons into certain States where, by the laws thereof, their admission is prohibited" has been supposed to be a precedent. This act, on examination, will be found to have no bearing on the question of derivative power. It was passed in virtue of an original constitutional authority in Congress over the subject on which it operated. The act, it will be observed, was passed in 1803, and provided for the punishment, not specially of the officers of Government, but of all persons who should be concerned in the importation of slaves into any State which had prohibited, or should prohibit their importation. It did not refer to the State laws for a description of the offence, but fully defined it. Now for the constitutional ground on which this act rested. The 9th section of the 1 st article of the Constitution, so far as it is material to this question, is as follows: "The migration or importation of such persons, as any of the States now existing shall think proper to admit, shall not be prohibited by Congress prior to the year one thousand eight hundred and eight." This article was a temporary and limited restriction on the general power of Congress "to regulate commerce." Without it, Congress might have immediately prohibited the importation of slaves into all the States; but, with it, Congress could not, until the year 1808, prohibit their importation into any of the States that should think proper to admit them. On the power of Congress to prohibit their importation into such States as should not think to admit them, this article of the Constitution imposed no restriction. Previous to the year 1808, several of the States having prohibited the admission of slaves, the original authority of Congress over the subject, under the power "to regulate commerce," came into full operation, so far as it respected those States, and under that power the act under considera- 
tion was passed. It is therefore, apparent that this act is no precedent for the derivative power contended for, but is only an example of the exercise of original constitutional authority.

The act of February 25, 1799, entitled "An act respecting quarantine and health laws," rests also on the same original constitutional basis. That act, in substance, recognizes the validity of the quarantine and health laws of the States, and directs the revenue and other officers of the Government to cooperate with the State authorities in their execution. These laws act upon a subject on which the powers of the General Government and those of the State Governments were peculiarly liable to produce conflicting legislation. The General Govemment has the exclusive power "to regulate commerce with foreign nations and among the States." Health regulations, being matters of internal police, belong exclusively to the States. The laws which might be passed by the two authorities, under these two powers would frequently operate on precisely the same thing. The same cargo of goods which was the subject of commerce, might also contain the seeds of disease. In order to promote the objects of commerce, Congress might desire that, immediately on the arrival of the cargo, it should be landed and put on sale at the usual place for carrying on the business of merchandise. The State, to prevent the danger of infection might wish to prohibit the landing of the cargo within its port of destination for a period of time. Here were two opposite independent powers, each exercising an acknowledged constitutional authority, and their legislation coming directly in conflict. What was to be done? Congress declared that it would so exercise its power of regulating commerce as not to interfere with the reasonable health laws of the States. The term reasonable is used, because the act prescribes certain boundaries, beyond which Congress would not suffer health laws to operate. This act is undoubtedly a precedent to show a commendable disposition in the General Government to prevent its powers from conflicting with those of the States. But it is no precedent to prove that Congress can derive any constitutional power from State laws, or that it can co-operate in their execution by any species of legislation prohibited to Congress by the Constitution. It is, at most, an example of the voluntary forbearance of Congress to exercise, in a manner not forbidden, one of its acknowledged powers. It is also to be remarked, in regard to this law, that it imposes no penalty on the officers of Government for neglecting to co-operate in the execution of the health laws. A person appointed to office under the General Government, is not thereby released from his obligation to the State in which he may be. In like manner as before his appointment, he is bound to obey the laws of such State, and aid in their execution, so far as they are not inconsistent with the paramount laws of the General Government.

The directions in this statute, though they pointed out to the officer a proper course of action, did not place him under any additional legal obligation, or impose on him any new penal liability. The directions were properly given in this instance, because they related to a point of duty, about which, from the apparently conflicting powers of the two 
Governments, the officer was greatly liable to doubt; and because they referred to a State law, in the execution of which the aid of such officer was likely to prove peculiarly useful and efficient. In so far as Congress, by this act, might be considered as making the health laws legitimate regulations of commerce, Congress might doubtless have provided a punishment for their violation. But so far as they remained properly health laws, the punishment could only be inflicted by the States. The omission of Congress to provide a punishment is evidence that they were deemed as still continuing to be purely health laws, and subject only to State punishment. The same rule must apply to "incendiary publications." So far as their circulation may be constitutionally restricted by Congress under its post office power, so far may Congress extend its penal sanctions; but, wherever its delegated powers cease, there must Congress cease to act. We are then thrown back on the question of what authority Congress possesses over "incendiary publications," by the grants of power contained in the Constitution, under the restrictions on the exercise of those powers found in that instrument?-a question which will be presently examined.

Various modifications of this third species of legislation, more or less limited in their operation, have been suggested, but they all not on the same basis, and must stand or fall by the same arguments. Whether the law prohibited the reception and transmission of publications, or merely their delivery out of the Post Office, its principle is the same; depending for its support on a supposed power in Congress to look into the character and judge of the tendency of the productions of the Press. The mode which this species of legislation provides, for executing the judgment which the Government forms of the character of publications, is most exceptionable and alarming. It does not, like other statutes, provide for the trial and punishment of the actual offender, but for the manual seizure and destruction of the article which it judges to be offensive. It deprives the citizen of his right of trial by jury to determine the fact of the unlawfulness of the publication, and takes from him his property without any "process of law" whatever. In this respect it is a direct violation of the fifth article of the amendment to the constitution. It is a censorship of the Press, committed to this summary discretion of any single Post Master--a censorship exercised in secret and upon evidence which can only be reached by an inquisitorial scrutiny into the contents of the mails, which must at once destroy all confidence in this security for any purpose. It is believed that a law with such odious features could not long be tolerated by any free people.

The minority will now notice, briefly, the fourth proposed mode of legislation - that of making it an offence against the United States for any person to send through the mail into the slaveholding States any publications which, in the opinion of Congress, described in the act, would tend to instigate the slaves to insurrection.

It is obvious that this mode of legislation, though limited in its operation to the specific evil complained of in the message, is precisely the same in principle with those which include other publications than those 
on the subject of slavery. The same process of reasoning which would admit in Congress a power to determine what publications would have a tendency to instigate a servile insurrection, and to restrain their circulation, would allow the same body a power to determine what publications would tend to excite a political revolt, and draw after it the same power of proscription. The extensive provisions of the former proposed modes of legislation would, therefore, do no violence to the principles of this; but would merely serve as an illustration of those principles, by carrying them out to some of their alarming consequences.

The minority have not been able to come to the conclusion that Congress possesses the constitutional power to restrain the mail circulation of the publications specified in the message. On the contrary, they believe that any legislation for that purpose would come in direct conflict with that clause in the Constitution which prohibits Congress from making any law "abridging the freedom of speech. or of the press."

Having already seen that the effect of this restriction in the Constitution cannot be evaded by any reference to State legislation, the direct argument on this question is brief. After stating the prohibitory clause of the Constitution, it only remains to show that the exercise of a power by Congress to discriminate between the sentiments and opinions contained in different publications, and to prohibit the mail circulation of such as Congress chooses to consider of evil tendency, allowing to all others the benefit of a free circulation would be an abridgment of the freedom of the press; a proposition which, it appears to the undersigned, needs only to be stated to meet with universal assent.

The meaning of the term abridge is not qualified in the Constitution by the specification of any particular degree beyond which the liberty of the press is not permitted to be diminished. The slightest contraction or lessening of that liberty is forbidden. Nor does the Constitution point out any particular mode by which the freedom of the press may not be abridged. All modes of abridgment whatever are excluded, whether by the establishment of a censorship, the imposition of punishments, a tax on the promulgation of obnoxious opinions, or by any other means which can be devised to give a legislative preference, either in publication or circulation, to one sentiment emanating from the press, over that of another. Otherwise, the clause, by being susceptible of evasion, would be nugatory and useless. It was not against particular forms of legislation but to secure the substance of the freedom of the press, that the clause was made a part of the Constitution. The object of publication is circulation. The mere power to print, without the liberty to circulate, would be utterly valueless. The Post Office power, which belongs to the General Government, is an exclusive power. Under that power Congress has the entire control of the whole regular circulation of the country. Neither a State nor individuals, in opposition to the will of Congress, can establish or carry on the business of such circulation. A power, therefore, in Congress to judge of the moral, religious, political, or physical tendency of publications, and to deny the medium of mail circulation to those it deemed of an obnoxious 
character, would not only enable Congress to abridge the freedom of the press, but absolutely and completely to destroy it. Even under the practical operation of the present Post Office laws, (and they may be constitutionally amended until Congress shall exercise the most perfect monopoly of disseminating information,) the prohibition of the mail circulation of any publication for which such circulation was desired, would be one of the highest degrees of abridgment of the freedom of the press. No periodical in the country which was prohibited a mail circulation could compete with its antagonist publication to which that privilege was allowed with the smallest hope of success.

Here the minority believe they might safely rest the argument against the constitutionality of the legislation suggested in the message of the President; but the importance of the subject, as well as a respect for those who have maintained a different opinion, seem to call for a still further examination.

The constitutionality of a law having for its object the suppression of "incendiary publications" is not sustained by any precedent which the history of our legislation affords. The sedition act of 1798 falls far short of being such a precedent. In regard to the sedition act two things are to be noticed: First, in order to constitute the offence, the publications must have been directed against the Government of the United States, its officers or authority; and, secondly, the publications must have been false, and the defendant might prove their truth in justification. In favor of the power of Congress to pass this act, it was argued "that a law to punish false, scandalous, and malicious writings against the Government of the United States,with intent to stir up sedition against that Govemment, was a law necessary and proper for carrying into effect the powers vested by the Constitution in the Government of the United States: that libels against that Government were offences arising under the Constitution, and consequently punishable before the Federal Courts." [See the report of a Committee of Congress on the alien and sedition acts, February 21, 1799.] There is no pretense that the publications which Congress is now called upon to suppress are directed against the General Government, or have any tendency to endanger or disturb its authority. It is the State authorities which are alleged to be endangered by the "incendiary publications," and consequently a law to suppress them would be beyond the principle of the sedition act, and unsustained by the argument in favor of its constitutionality. Indeed, the principle of the legislation now sought would, so far as their mail circulation was concerned, assert a jurisdiction in Congress over the whole subject of libels, whether against the Government or individuals; an extent of jurisdiction of which the framers of the sedition act could never have even dreamed. It was further argued in favor of the sedition act, that it was no violation of the article of the Constitution which prohibited Congress from making any law "abridging the freedom of the press," because it was said, the genuine freedom of the press consisted in the liberty to publish without restraint the truth, and that it could be no abridgment of that freedom to punish the publication of falsehood. In the 
legislation now in contemplation, the prohibitory clause of the Constitution is not even sought to be evaded, by allowing the truth to be given in evidence in justification of the publication. Whether true or false, the offence will be equally criminal, and the punishment in all probability equally severe. The sedition act is, therefore, no precedent for any of the principles of the legislation which is required to suppress the circulation of "incendiary publications."

Those who denied the constitutionality of the sedition act, and among them Mr. Madison, in his elaborate and able report, made to the Virginia House of Delegates in 1799, contended that the clause of the Constitution which provides that Congress shall make no law "abridging the freedom of speech, or of the press," was to be understood as a clear prohibition of all power in Congress over the subject of the press, and that consequently Congress could make no law in any manner affecting it, or in other words, could express no legislative opinion of the character and tendency of its productions. This doctrine is believed to have obtained the almost universal assent of the People of the United States, and especially of that portion of the People of the Union for whose peculiar benefit the proposed legislation is intended. In this doctrine the undersigned concur; and if it be admitted as the true doctrine, if it be admitted that Congress can make no law in any manner affecting the press, they cannot conceive what possible ground remains for argument, in favor of the constitutionality of the legislation now in contemplation.

But it is contended that Congress has authority to legislate for the suppression of the mail circulation of "incendiary publications," under the special power "to establish post offices and post roads," and the general power "to make all laws necessary and proper for carrying into execution" that power; and it is argued that the suppression of the mail circulation of these publications would be a legitimate regulation of the Post Office Department; that the Post Office Department is to be considered as an instrument in the hands of the Government for beneficial purposes, and that Congress may well pass any law which shall prevent the use of that instrument for purposes of mischief.

It will be readily conceded that Congress, under the post office power, may make any law which is necessary and proper to secure the safe, convenient, and expeditious transportation of the mail. With this object in view, Congress may prescribe the weight, the bulk, and mechanical form of packages, and the nature of the material of which the article to be transported shall consist; and should the great object of the mail establishment, the safe and expeditious dissemination of information from one part of the country to another, ever require the sacrifice, Congress may prohibit the circulation of particular classes of publications, as pamphlets, magazines, and even newspapers. Nor will the undersigned undertake to say that Congress could not, under its post office power, prohibit the use of the mail for transportation of articles calculated to produce mischief or crime, in cases where its legislation would not come in conflict with any of the prohibitory clauses of the Constitution. The sending 
through the mail of forged papers, as checks, drafts, or bank bills, might present a strong case to the consideration of Congress; and it is not necessary, in the view which the undersigned take of the subject under examination, to inquire into the constitutionality of a law to meet cases of that description.

The minority hold that, in the execution of the powers conferred by the Constitution, Congress must confine itself to the legitimate object of those powers, and that Congress, under color of executing any particular power, cannot enter on ground on which it is forbidden to tread by the prohibitory clauses of the Constitution. They hold that the prohibitory clauses of the Constitution are co-extensive with the whole instrument; that they restrain, absolutely and completely, the conferred powers, and that they cannot, under any presence, be violated without a violation of the Constitution. Congress cannot, for instance, however urgent the necessity may seem, "suspend the privilege of the writ of habeas corpus, but in cases of rebellion or invasion," or, under any circumstances, "pass any bill of attainder or ex post facto law," or "grant any title of nobility," or "infringe upon the right of the People to keep and bear arms," or direct "private property to be taken for public use without just compensation," or "make any law respecting an establishment of religion, or prohibiting the free exercise thereof." Nor can Congress, under color of the post office, or any other power, "make any law abridging the freedom of speech, or of the press." Congress cannot do this, for the very plain and simple reason that the Constitution no where says Congress may, but, on the contrary, expressly and positively says Congress shall not.

A question having some analogy to that under present examination, has been heretofore discussed with much ability, by committees of both Houses of Congress. It arose under this very post office power, and the legislation sought was denied, on the ground that it would infringe that prohibitory clause of the Constitution which provides that "Congress shall make no law respecting an establishment of religion, or prohibiting the free exercise thereof"; a clause which is found in the same article with that relating to the freedom of the press, and to which, in its nature, it is very nearly allied. The minority refer to the adverse reports of the committees of the Senate and House, on the memorable petitions for the discontinuance of Sunday mails. It is to be observed, that a law for discontinuing those mails could not be said to be strictly a law "respecting an establishment of religion," because no such establishment existed in the country, and the proposed law would not constitute such establishment. Nor could it be alleged that such a law would actually "prohibit the free exercise of religion;" for it was not pretended that any person did make, or could make it, a matter of conscience to be allowed to transport the mails, or to send or receive letters on Sunday. Nor could it be charged against such a law that it would give any preference in privileges to the followers of one religion over those of another; for the law would be equal in its operation, affecting alike those of every faith. The principle on which those reports were founded could be no other than this: that the 
Government could not recognize the religious belief of a part of its citizens, as the ground for legislation, that should deprive the whole of them of a privilege which they might otherwise enjoy. It was said by those committees that the convenience and usefulness of the mail establishment forbid the proposed change; and they argued with much force and eloquence, that a determination in favor of the prayer of the petitions would involve Congress in a legislative decision of the religious controversy pending between those who held to the divine obligation of the Sabbath and those who denied it; and that making a point of religious belief the basis of legislation would violate the spirit of the Constitution, and be highly dangerous as a precedent. On this ground the prayer of those petitions was denied, and the country has cheerfully responded to the propriety of the decision. It is obvious that the principle on which the legislation now contemplated rests, would be a much clearer infringement of the Constitution than that adjudicated by those committees.

If the petitions, before referred to, instead of asking for a discontinuance of Sunday mails, had alleged that publications impugning the divine obligation of the Sabbath were of immoral and dangerous tendency, and had prayed Congress to prohibit their mail circulation, there would have been presented a question precisely in principle with that now before Congress. The favorable decision of such a question, these committees might well have said, would not only "involve Congress in a legislative decision of a religious controversy," but, by giving a preference in privileges to men of one religious faith over those of another, would be a direct violation of that article of the Constitution which secures to all "the free exercise of religion." And they might have added, that as such decision would also give a preference to publications advocating one sentiment over those advocating another, it would be a like violation of the other clause of the same article, which prohibits Congress from making any law "abridging the freedom of the press." Supposing this change of question, the minority cannot doubt that the reports of those committees would have been as decidedly adverse, their argument as eloquent and convincing, and the judgment of the country no less uniform and conclusive.

The prohibition of "incendiary publications" from mail circulation is not within the legitimate scope of the post office power; the power of proscribing them not being at all necessary to the safe, convenient, or expeditious transportation of the mail. They can as well be conveyed as any other publications of the same form and size. A law to prevent their circulation would be founded in erroneous and unconstitutional principles. Under color of providing for the convenient transportation of the mail, and of preventing its use for evil purposes, it would assume a power in Congress to judge of the tendency of opinions emanating from the press; a power to discriminate between packages, not in reference to their bulk or form, but in relation to the sentiments they might be designed to inculcate. One class of opinions, meeting the approbation of Congress, is permitted a free circulation; another class of opinions, which Congress denominate "dangerous, seditious, and incendiary," is prohibited. This is one of the 
very cases on which the prohibition in the Constitution was designed to operate. The framers of this article of amendment never could have had any apprehension that Congress would undertake to restrain all publications. History had taught no such lesson. No Government, however despotic or tyrannical, ever desired to exercise such a power. Even in the Ottoman Empire, a man might always have written a panegyric on the reigning Sultan, or any of his favorite institutions, without incurring the slightest danger of the bowstring. The safe, the peaceful, the loyal publications were never any where proscribed. It is only on the dangerous, the seditious, the incendiary, that the iron grasp of Government is ever laid. All the decrees and edicts which, in any country, have ever been issued to trammel the productions of the pen, from the bull of Leo, thundered on the publications of Luther, down to the ordinance of Charles the Tenth, for sealing up in a public depot the printing press of France, hold one uniform language. They are all promulgated to prevent the perils of insurrection, and all directed against dangerous, seditious, and incendiary publications. If it be said that the publications which we are now called upon to suppress are really and truly dangerous, seditious, and incendiary, then the minority say they are really and truly some of the precise publications against which it was designed by the Constitution that Congress should have no power to legislate. The People of the United States never intended that the Government of the Union should exercise over the press the power of discriminating between true and erroneous opinions, of determining that this sentiment was patriotic, that seditious and incendiary, and therefore wisely prohibited Congress all power over the subject. The minority of the committee respectfully submit to the House that Congress does not possess the constitutional power to distinguish from other publications, of like size and form, the "incendiary publications" specified in the Message of the President, or in any way to restrain their mail circulation. 